\title{
Reduction of Sulphur Content of Urals Crude Oil Prior to Processing Using Oxidative Desulphurization
}

\author{
*A. Abubakar, I.A. Mohammed-Dabo and A.S. Ahmed \\ Department of Chemical Engineering, Ahmadu Bello University, Zaria, Nigeria \\ [*Corresponding Author: Email abubakara@abu.edu.ng; : : +2348036951137]
}

\begin{abstract}
The presence of sulphur in crude oil poses enormous challenges as regards its negative environmental and economic impacts. As such, the safety of the personnel and the equipment is at high risk during the processing of Urals crude oil in Kaduna Refining and Petrochemical Company (KRPC) because of its sour nature. This study was aimed at reducing the sulphur content of the Urals crude oil prior to processing by subjecting it to oxidative desulphurization where peracetic acid was used as the oxidant in the actual mass-to-stoichiometric mass ratio ranging from 1 to 5 . The oxidized sulphur compounds were thereafter extracted using acetic acid as the extraction solvent. Furthermore, atmospheric distillation was carried out on both the raw and the desulphurized crude oil samples. Finally, the sulphur contents of the various crude oil samples and their fractions were analyzed. The results showed drastic reductions in the sulphur contents up to actual mass-to-stoichiometric mass ratio of 2 but the reductions became progressively insignificant afterwards. Meanwhile, the highest reduction in the sulphur content of the crude oil was $61.6 \%$ while those of the gasoline, kerosene, diesel and residue were 32.0, 45.1, 68.9 and $75.0 \%$ respectively. Therefore, peracetic acid is an effective oxidant for oxidative desulphurization of the crude oil.

Keywords: Sulphur content, Crude oil, Oxidative desulphurization, Thiophenic compounds
\end{abstract}

\section{INTRODUCTION}

The presence of sulphur has a very great influence on the value of the crude oils because of the negative environmental impact and the effect ofthe refined products on automotive and combustion engines. This has led to the stringent environmental regulations which place considerable pressure on refinery operators worldwide to reduce sulphur contents of crude oil products (Rasina and Rudin, 1988; James, 1999; Matar and Hatch, 2000; Germain and Herman, 2003; Prasad, 2006). In the past decades, more and more stringent legislations on the specifications of sulphur level in fuels have been passed in many countries and currently the production of ultra-low sulphur fuel oil has become an important task of oil refining industry (Zhanget al., 2009).

Active sulphur includes elemental sulphur, hydrogen sulphide and mercaptan while the inactive onesinclude sulphide, carbon disulphide, thiophene (TH), and so on. It has been found that in fluid catalytic cracking (FCC) gasoline, more than $90 \%$ sulphur exists in the form of thiophene and its derivatives, while in diesel, thiophenic sulphur accounted for $80 \%$ of the total sulphur, and benzothiophene (BT) and dibenzothiophene (DBT) accounts for more than $70 \%$ of this thiophenic category (Zhang et al., 2009). As a result, removal of sulphur in thiophenes is the main desulphurization focus of this study.

In addition, the current requirement of sulphur level in transportation fuels has shifted the attention of crude oil refiners from the convectional HDS to other processes. In recent years, industry has sought to develop less expensive desulphurization alternatives to hydrotreating. One of such alternatives that have been successful in meeting this requirement is the oxidative desulphurization which uses organic or inorganic peroxides as oxidants (McKinley, 2003).

Itis known that contacting petroleum fuelswith an oxidant converts the organosulphur and nitrogen compounds in the fuels into sulphones (or sulphoxides) and organic nitric oxides, respectively. These polar organic oxides can be removed from the fuels by solvent extraction and/or adsorption(Rang, 2006). More importantly, oxidative desulphurization can easily oxidize and remove thiophenic sulphur compounds, which cannot be readily treated by HDS due to the stereo hindrance effect around the sulphur atom in the molecule (Zhang, 2009).

Different researchers have made tremendous breakthroughs in desulphuring crude oils fractions (Collins et al., 1997; Cullen, 2004; Ali et al., 2006; 
Ranget al., 2006; Zhang et al., 2009; Brown and Evans, 2009). An interesting process was worked out by desulphurizing petroleum oils with nitrogen oxides and oxygen to convert organic sulphur into sulphur trioxide which was absorbed with concentrated sulphuric acid (Guth et al., 1975). The most desirable result was obtained by peroxy acid oxidation $\left(\mathrm{HCOOH} / \mathrm{H}_{2} \mathrm{O}_{2}\right)$ after which the sulphones and the sulphoxides created during oxidation was carried out by extraction followed by adsorption with silica gel to reach sulphur content levels of $7.0 \mathrm{ppm}$ and $0.00 \%$, respectively (Aida et al., 2000). Another effective process has been suggested by Mei et al. (2003). Phosphotungstenic acid, tetraoctyl ammonium bromide and ultrasound were used at $75{ }^{\circ} \mathrm{C}$ to complete the oxidation. The oxidized product was then extracted with acetonitrile. Under these conditions dibenzothiophene and its derivatives were removed from diesel fuel at a rate of more than $99 \%$. In recent years many desulphurization processes with peroxides have been patented: removal of sulphur from 250 to 5 ppm in diesel fuel (Rappas, 2002), sulphur removal in diesel fuel from 0.557 to $0.0008 \%$ (Gunnerman, 2002), and from gas oil to $82 \%$ (Gore et al., 2003). In 2004, a patent application concerning desulphurization with oxidation was presented (Rang, 2006). Oxidation of crude oil was carried out by hydrogen peroxide in the presence of a catalyst, surface-active agent and radiation with sonic energy at $125{ }^{\circ} \mathrm{C}$ and $3 \mathrm{~atm}$. The resulting sulphur content was reduced from $2.5 \%$ to $0.7 \%$ (Cullen, 2004). Li et al (2004) suggested an interesting oxidation catalyst which is also phase transfer agent. Oxidation was carried out using

\section{MATERIALS AND METHODS \\ Oxidation process}

Two conical flasks were each filled with half (0.5) litre of Urals crude oil which weighed $412.68 \mathrm{~g}$ with sulphur content of $1.12 \mathrm{wt} \%$. According to the stoichiometric ratio of the oxidation of DBT by peracetic acid (PAA) which is $1: 2$ as represented by the equation in Figure 1, about $54.88 \mathrm{~g}$ of $40 \mathrm{wt} \%$ PAA solution was added to each flask.

The same $54.88 \mathrm{~g}$ of acetone was added to each mixture to minimize phase separation as the amount of acetic acid generated would be too high to keep the reaction in a single phase. The filled conical flasks were placed on a Stuart magnetic stirrer heater and the hydrogen peroxide for 30 minutes at $60{ }^{\circ} \mathrm{C}$ and 8 minutes at $90{ }^{\circ} \mathrm{C}$. The turnover number was estimated to be higher than 300 . After the process the catalyst was separated by centrifugation, and oxidized sulphur compounds were removed with extraction by $\mathrm{N}$-methyl2-pyrrolidone. Ultra-deep desulphurization with sulphur content below $0.1 \mathrm{ppm}$ in diesel fuel was achieved. The feed-stock was prehydrotreated diesel fuel, containing sulphur 0.053 wt \%. In a patent application, it was shown that sulphone obtained from dibenzothiophene, created in oxidation process, was converted into biphenyl and hydrogen sulphide by hydrogenation (Levy et al., 2003). Dibenzothiophene sulphone was hydrogenated under milder conditions than dibenzothiophene. A product containing $55 \mathrm{ppm}$ sulphur was obtained from gas oil in a two-step process. Also recently, several patent applications concerning oxidation with ozone and oxygen have been presented (Rang, 2006). In another application, heterogeneous oxidation of transport fuel with oxygen in the presence of a solid catalyst at temperature of $160{ }^{\circ} \mathrm{C}$ and pressure of $14 \mathrm{~atm}$, reduced sulphur content from 233 ppm to 12 ppm (95\% removal) (Hagen et al., 2004). Lin et al (2007) used non-aqueous peracetic acid solution and reduced the sulphur content of treated diesel from 198 to $5 \mathrm{ppm}$ after oxidation at $60{ }^{\circ} \mathrm{C}$ for 20 minutes, water washing and adsorption with alumina. Using treated light gas oil(LGO), it was reduced from 307 to $88 \mathrm{ppm}$ after oxidation at $50{ }^{\circ} \mathrm{C}$ for 15 minutes and extraction with acetic acid.

temperature was raised to $50{ }^{\circ} \mathrm{C}$ and maintained at this temperature for 20 minutes. Four other similar oxidations were carried out using 2, 3, 4 and 5 times the stoichiometric amount of the oxidant to obtain five different oxidized crude oil samples. These were respectively termed as $1: 1,2: 1,3: 1,4: 1$ and $5: 1$ crude oil samples.

Each of the oxidized crude oil was washed with water to remove the acetone added during oxidation. Acetic acid in oil-to-solvent ratio of 1:1 was mixed thoroughly and poured into separating funnel. The mixture was allowed to stand for 6 hours to ensure complete separation. The extract which contained the sulphones and the sulphoxides was drained off while the raffinate was collected as the desulphurized crude oil. 


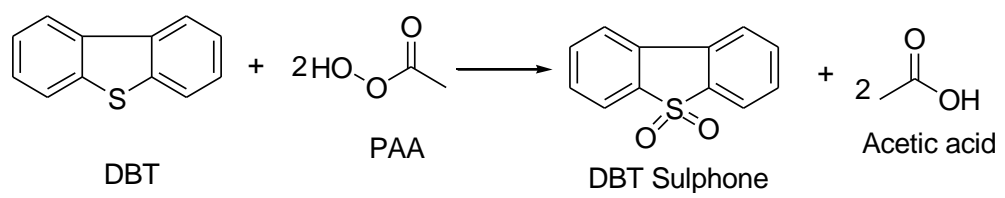

Figure 1: Extraction process of the oxidized sulphur compounds

\section{Atmospheric distillation process}

The raw and all the desulphurized crude oil samples were each distilled twice using ASTM 86-15 (2015) procedure and the following fractions were collected and weighed. Gasoline (IBP-170 $\left.{ }^{\circ} \mathrm{C}\right)$, kerosene (170$\left.240{ }^{\circ} \mathrm{C}\right)$, diesel $\left(240-340{ }^{\circ} \mathrm{C}\right)$ and residue $\left(>340^{\circ} \mathrm{C}\right)$. The average mass of each fraction for each sample of the crude oil was calculated. Atmospheric distillation set-up was used and it basically consists of heating bath, distillation flask and column, condenser and water chiller. The temperature was monitored using a thermometer inserted inside the distillation flask and the chiller supplied cold water to the condenser.

\section{Determination of sulphur content by Horiba Sulphur-In-Oil Analyzer (ASTM D4294)}

The analyzer (SLFA-1100) employed energy dispersive $X$-ray fluorescence technique. The sample cell was filled with each of the samples for analysis in turn to at least three quarter of its capacity $(10 \mathrm{ml})$ and covered with X-ray transparent plastic film window. The covered sample cell was turned upside down and placed on the cell table and closed. After setting the analyzer using the soft keys on the panel to give three different readings at 30 second intervals, the power switch was turned on and the three readings were displayed at the set time. The readings (in wt \%) were taken and their average was calculated and recorded.

\section{RESULTS AND DISCUSSIONS}

Table 1 presents the product yields of the atmospheric distillation of the crude oil samples. The gasoline fraction yield show highest value of $15.26 \mathrm{wt} \%$ in the raw crude oil and lowest value of $13.57 \mathrm{wt} \%$ in the 1:1 crude oil. However, there was steady increase in the yield within the desulphurized gasoline fractions as the amount of the oxidant increased. In the kerosene fractions, the table show that the lowest yield of 12.62 wt $\%$ was obtained from the raw crude oil while the highest value of $13.74 \mathrm{wt} \%$ was obtained from the 5:1 crude oil. In the diesel fractions, it can be seen that the yields from the desulphurized crude oil were higher than the one from the crude oil. The yield of the residue has similar trend with that of the diesel. The inconsistent trends in the yields of all the fractions can be attributed to the removal of molecules containing sulphur by oxidative desulphurization as it affects the composition of the crude oil (Grossmanet al., 1999).

Table 1: Comparison of Product Yields of the Crude Oil Distillation

\begin{tabular}{lllllll}
\hline \multirow{2}{*}{ Fraction } & $\begin{array}{l}\text { Raw oil } \\
\text { (wt \%) }\end{array}$ & \multicolumn{5}{l}{ Desulphurized oil with different amount of oxidant (wt \%) } \\
\cline { 3 - 7 } & $1: 1$ & $2: 1$ & $3: 1$ & $4: 1$ & $5: 1$ \\
\hline Gasoline $\left(\right.$ (BP-170 $\left.{ }^{\circ} \mathrm{C}\right)$ & 15.26 & 13.57 & 14.07 & 15.14 & 15.25 & 15.18 \\
Kerosene $\left(170-240^{\circ} \mathrm{C}\right)$ & 12.62 & 13.02 & 13.13 & 13.48 & 13.42 & 13.74 \\
Diesel $\left(240-340^{\circ} \mathrm{C}\right)$ & 31.91 & 32.34 & 31.45 & 32.68 & 33.13 & 32.89 \\
Residue $\left(>340^{\circ} \mathrm{C}\right)$ & 34.00 & 35.07 & 35.63 & 33.77 & 32.58 & 32.25 \\
Subtotal & 93.79 & 94.0 & 94.28 & 95.07 & 94.38 & 94.06 \\
Loss & 6.21 & 6.0 & 5.72 & 4.93 & 5.62 & 5.94 \\
Total & $\mathbf{1 0 0 . 0 0}$ & $\mathbf{1 0 0 . 0 0}$ & $\mathbf{1 0 0 . 0 0}$ & $\mathbf{1 0 0 . 0 0}$ & $\mathbf{1 0 0 . 0 0}$ & $\mathbf{1 0 0 . 0 0}$ \\
\hline
\end{tabular}

Table 2 shows the results of sulphur content determination. The sulphur content of the crude oil was reduced from 1.1326 to $0.4349 \mathrm{wt} \%$ after using five times the stoichiometric amount of the oxidant. This translated to about $62 \%$ reduction as shown in Figure 2. Similarly, the sulphur contents in gasoline, kerosene, diesel and residue fractions were reduced from 0.0805 to 0.0547 wt $\%, 0.2086$ to 0.1145 wt $\%, 0.7754$ to
0.2408 wt $\%$ and 1.6426 to 0.4110 wt $\%$ respectively. However, it can be seen that percentage reductions of the sulphur contents in gasoline $(32.0 \%)$ and kerosene $(45 \%)$ were not much compared to what were recorded in diesel $(69 \%)$ and residue $(75 \%)$. This is due to the fact that the thiophenic compounds which are easily oxidized by this process are mostly concentrated in heavier fractions. In addition, Figure 3 reveals that this 
process was very effective up to three times the stoichiometric amounts of the oxidant as further increase did not make significant reduction of the sulphur contents.

Table 2: Average Sulphur Contents of Crude Oil, Its Fractions and Extracts

\begin{tabular}{lllllll}
\hline \multirow{2}{*}{ Sample } & $\begin{array}{c}\text { Raw oil } \\
\text { (wt \%) }\end{array}$ & \multicolumn{5}{l}{ Desulphurized oil with different amounts of oxidant (wt \%) } \\
\cline { 3 - 7 } & $1: 1$ & $2: 1$ & $3: 1$ & $4: 1$ & $5: 1$ \\
\hline Crude & 1.1326 & 0.7439 & 0.5806 & 0.4985 & 0.4580 & 0.4349 \\
Gasoline & 0.0805 & 0.0716 & 0.0574 & 0.0554 & 0.0548 & 0.0547 \\
Kerosene & 0.2086 & 0.1686 & 0.1261 & 0.1189 & 0.1150 & 0.1145 \\
Diesel & 0.7754 & 0.5150 & 0.3148 & 0.2698 & 0.2524 & 0.2408 \\
Residue & 1.6426 & 1.0701 & 0.5817 & 0.4643 & 0.4330 & 0.4110 \\
Extract & - & 0.0748 & 0.1635 & 0.1907 & 0.2147 & 0.2209 \\
\hline
\end{tabular}

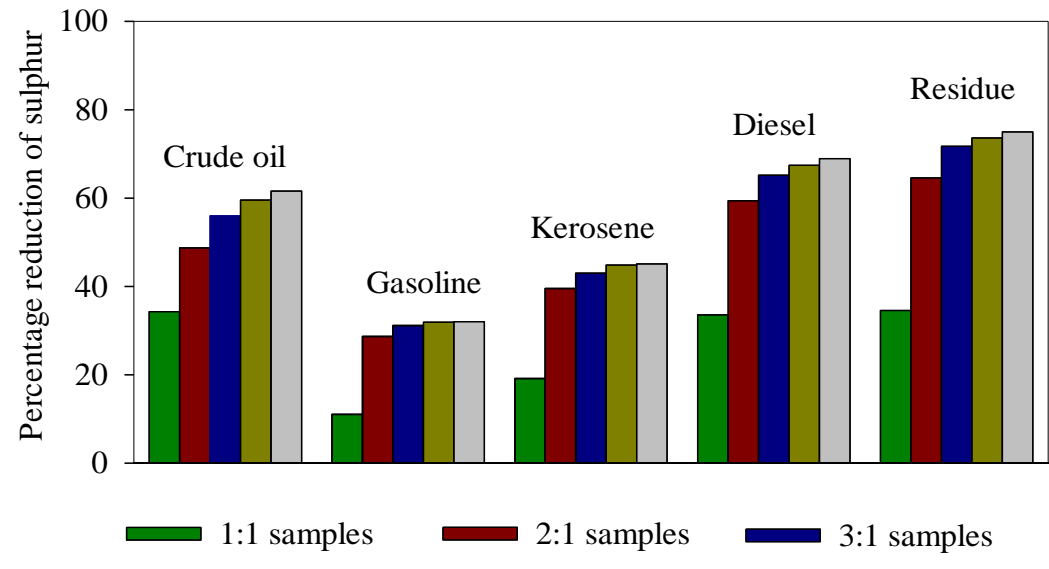

4:1 samples

ए:1 samples

Figure 2: Relative level of sulphur reduction of crude oil and its fractions

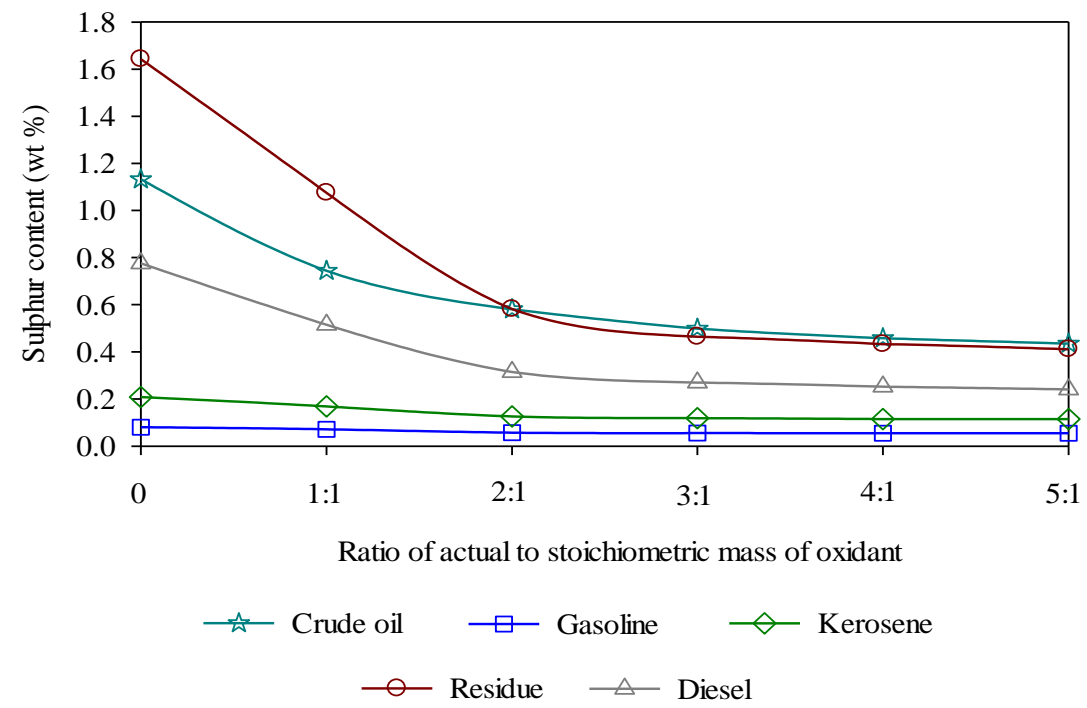

Figure 3: Reduction of sulphur contents of treated crude oil and its fractions 


\section{CONCLUSIONS}

From the results obtained, it can be concluded that the difference in the product yields of the raw crude oil and those of the desulphurized crude oil samples were not very much. Therefore, oxidative desulphurization does not significantly affect the product yield. The sulphur contents of the raw crude oil and oxidant in the ratio of $1: 1,2: 1,3: 1,4: 1$ and $5: 1$ crude oil samples were respectively $1.1326,0.7439,0.5806,0.4985,0.4580$ and $0.4349 \mathrm{wt} \%$. This shows that the reduction in the sulphur content of the crude oil increased with increase in the amount of the oxidant. The sulphur content reduction of the fractions shows the same trend with that of the crude oil. The gasoline, kerosene, diesel and residue sulphur contents were reduced respectively from 0.0805 to 0.0548 wt $\%, 0.2086$ to 0.1150 wt \%, 0.7754 to 0.2698 wt $\%$ and 1.6426 to 0.4110 wt \%. For economic reasons, the maximum amount of the oxidant that should be used is when the stoichiometric amount of the oxidant is doubled as no significant change was observed when higher ratios of oxidant were used. The qualities of the crude oil and its fractions were not very much affected by this desulphurization when compared with the crude oil assay and KRPC specifications. The KRPC specifications of sulphur contents for the crude oil fractions were reached after using twice the stoichiometric amount of the oxidant.

\section{REFERENCES}

Aida, T., Yamamoto, D., Iwata, M. and Sakata, K. (2000). Development of Oxidative Desulphurization Process of Diesel Fuel. Chemical Journal,22:241-256.

Ali, M.F., Al-Malki, A., El-Ali, B. and Siddiqui, M.N. (2006). Desulphurization of Gasoline and Diesel fuels, using non-hydrogen consuming techniques. Fuel Journal, 85: 1354-1363.

ASTM D86-15 (2015). Standard Test Method for Distillation of Petroleum Products and Liquid Fuels at Atmospheric Pressure, ASTM International, West Conshohocken, PA, 2015, www.astm.org

Brown, F. and Evans, M. (2009). FCC Gasoline Sulphur Reduction Using Catalyst Additives Mechanisms and Commercial Experiences. INTERCAT ${ }^{\circledR}$ Inc., pp. $1-10$.

Collins, F.M., Sharp, C. and Lucy, A.R. (1997). Oxidative Desulphurization of Oils via Hydrogen Peroxide and Heteropolyanion Catalysis. Journal of Molecular Catalysis A: Chemical,117(1): 397403.
Cullen, M. (2004). Treatment of Crude Oil Fractions of Fossil Fuels and Products Thereof. United State Patent, 0074812 A1.

Germain, M. and Herman, V.W. (2003). Technology Developments Meet Refining Challenges. In: World Petroleum Congress. pp 134-140.

Gore, W., Bonde, S., Dolbare, G.E. and Skov, E.R. (2003). Method of Desulphurization and Dearomatization of Petroleum Liquids by Oxidation and Solvent Extraction. US Patent, 6596914 B2.

Grossman, M.J., Lee, M.K., Prince, R.C., Garrett, K.K., George, G.N. and Pickering, I.J. (1999). Microbial Desulfurization of a Crude Oil Middle-Distillate Fraction: Analysis of the Extent of Sulfur Removal and the Effect of Removal on Remaining Sulfur. Appl. Environ Microbiol. 65(1): 181-188.

Gunnerman, R.W. (2002). Continuous Process for Oxidative Desulphurization of Fossil Fuels with Ultrasound and Products Thereof. US Patent, 6500219 B1.

Guth, E.D., Helgeson, N.L., Arledge, K.W. and Brienza, A.R. (1975). Petroleum Oil Desulphurization Process, US Patent, 3 919, 402 Nov 11, 1975.

Hagen, G.P., Huff, G.A., Gong, W.H. and Regalbuto, M.C. (2004). Process for Oxygenation of Components for Refinery Blending of Transportation Fuels. US Patent, 0104144 A1.

James, G.S. (1999). The Chemistry and Technology of Petroleum. Third Edition, Revised and Expanded, Marcel Dekker Inc. New York. PP 215-357.

Levy, R.E., Stavros, A., Sudhakar, C., Nero, V.P., DeCanio, S.J. (2003). Hydrodesulphurization of Oxidized Sulfur Compounds in Liquid Hydrocarbons, US Patent, 009440 A1.

Li, C., Jiang, Z., Gao, J., Yang, Y., Wang, S., Tian, F., Sun, F., Sun, X., Ying, P. and Han, C. (2004). Ultra-deep Desulphurization of Diesel Fuel: Oxidation with RecoverableCatalyst Assembled in Emulsion. European Chemical Journal, 10: 22772280.

Lin, T. B., Huang, H.Y.; Hwang, J.H.; Shen, H.C. and Chuang, K.T. (2007). Oxidative Desulphurization and Denitrogenation of Petroleum Oils, US Patent, 7276152 B2.

Matar, S. and Hatch, L.F. (2000). Chemistry of Petrochemical Processes. Second Edition, Gulf Publishing Company, Houston, Texas. pp 12-28

McKinley, S. G. (2003). Deep desulfurization of petroleum feedstocks by selective adsorption and 
extraction. Ph.D. Thesis, lowa State University, USA.

Mei, H., Mei, B.M. and Yen, T.F. (2003). A New Method for Obtaining Ultra-low Sulphur Diesel Fuel via Ultrasound Assisted Oxidative Desulfurization. Fuel, 82(4): 405-414.

Prasad, R. (2006). Petroleum Refining Technology. First Edition, Khanna Publishers, NaiSarak, DelhiIndia.

Rang, H., Kann, J. and Oja, V. (2006). Advances in Desulphurization research of liquid fuel. Oil Shale, 23(2):164-176.
Rappas, A.S. (2002). Process for removing low amounts of organic sulphur from hydrocarbon fuels. US Patent 6402940 B1 June 11, 2002.

Rasina, M.G. and Rudin, M.G. (1988). The Chemistry and Technology of Petroleum and Gas. Mir Publishers, Moscow. pp 39-134.

Zhang, G., Yu, F. and Wang, R. (2009). Research Advances in Oxidative Desulphurization Technology for the Production of Low Sulphur Fuel Oils. Petroleum and Coal,51(3): 196-207. 